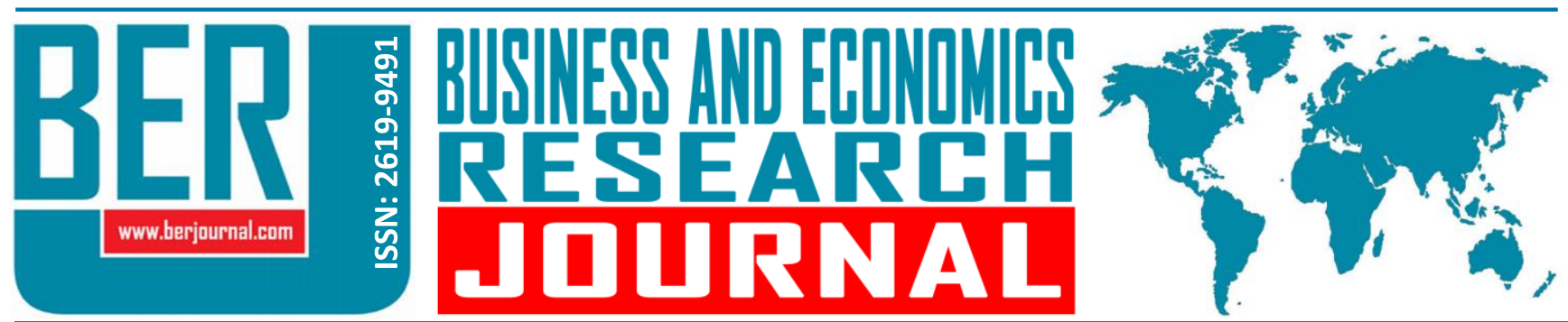

Business and Economics Research Journal Vol. 10, No. 3 Special Issue, 2019, pp. 671-685 doi: 10.20409/berj.2019.192

\title{
Özelleştirme Öncesi Yeniden Yapılandırma: Türk Kamu İktisadi Teşebbüsleri Üzerine Bir İnceleme ${ }^{1,2}$
}

\author{
Ismail Cagri Ozcan ${ }^{\mathrm{a}}$
}

Öz: Türkiye özelleştirme programını ilk başlatan ülkelerden biri olmasına rağmen bu programın uygulanma hızı oldukça yavaş kalmıştır. Özelleştirme programı kapsamına alınan kamu iktisadi teşebbüsleri (KiT'ler) uzun süre programda kalmaya devam etmişler, bazı KiT'ler ise hiç kapsama alınmamışlardır. Bu durum, KiT'lerin nasıl bir sıralamayla özelleştirme programı kapsamına alındıkları ve kapsama alınan KiT'lerin özelleştirilmelerine kadar geçen sürede nasıl bir yeniden yapılandırmadan geçtikleri sorularını beraberinde getirmektedir. Zira, hangi KiT'lerin özelleştirilmek üzere seçildikleri ve seçilen KiT'lerde hayata geçirilen yeniden yapılandırma faaliyetleri özelleştirmelerin başarııını doğrudan etkilemektedir. Bildiğimiz kadarıyla Türkiye üzerine bu konuda yapılmış bir araştırma bulunmamaktadır. Bu çalışma bahsedilen bu boşluğu doldurmak amacıyla, 1990-2001 döneminde hangi özellikleri taşıan KiT'lerin özelleştirme programı kapsamına alındığı ve kapsama dahil edilen KiT'lerde ne tür bir yeniden yapılandırmaya gidildiğini analiz etmektedir. Çalışmanın sonuçları, iktidarların özelleştirilmeleri daha kolay olan KiT'leri özelleștirme programı kapsamına almayı tercih ettiklerini göstermektedir. Çalıșmanın diğer bir sonucu, özelleştirme programı kapsamına alınan KiT'lerde özellikle kapsama alınmayı takip eden ilk sene içinde çeşitli yeniden yapılandırma faaliyetleri yürütülmüş olduğudur.

\section{Restructuring before Privatization: An Examination of the Turkish State-Owned Enterprises}

Abstract: Though Turkey is one of the initial countries that started a privatization program, the pace of the implementation of the privatization program has remained quite low. Many stateowned enterprises (SOES) stayed for a long time in the privatization program and many others are not even included in the privatization program. This situation arises the questions such as "what are the criteria for the SOEs to be included into the privatization portfolio" and "what kind of restructuring processes are these SOEs going through before the privatization". Because the selection of the SOEs to be privatized and the associated restructuring directly affect the success of the privatizations. There is no study on this topic to our knowledge for Turkey. This study aims at filling this gap by examining which SOEs were included into the privatization portfolio and what kind of restructuring processes these SOEs underwent over the 1990-2001 period. The findings of the study suggest that Turkish governments decided to privatize the SOEs that were easier to be privatized. Another finding is that the SOEs underwent a restructuring especially in the following year of being included into the privatization portfolio.

\section{Anahtar Sözcükler:}

Özelleştirme, Kamu-iktisadi Teşebbüsleri, Finansal Performans, Yeniden Yapılandırma

JEL: G32, G34, L32, L33

Düzeltme : 24 Mart 2019

Kabul : : 03 Nisan 2019

Tür : Araştırma

Keywords: Privatization, State-Owned Enterprises, Financial Performance, Restructuring

JEL: G32, G34, L32, L33

Received : 01 February 2019

Revised : 24 March 2019

Accepted : 03 April 2019

Type : Research 


\section{Giriş}

Kamu sahipliği ve işletmeciliğinin beraberinde getirdiği şeffaflık ve vekalet sorunları ile kamu teşebbüslerinin finansal zararları, kamu iktisadi teşebbüslerine (Кіт’lere) getirilen eleştirilerin giderek artmasına neden olmuştur. Yaşanan sorunlara çözüm bulmak amacıyla, bu teşebbüslerin ticarileştirilmeleri, şirketleştirilmeleri ve özelleş̧irilmeleri gibi çeşitli alternatifler hayata geçirilmeye çalışmıştır. Özelleştirmeler bu önlemlerden en tartışılanı olarak öne çıkmış ve yaklaşık son 40 yıllık dönemde kendisinden oldukça sık söz ettirmiştir.

Kapsamlı bir şekilde ilk olarak Birleşik Krallık'ta başlatılan özelleştirme uygulamaları, izleyen dönemde diğer birçok ülke tarafında da benimsenmiştir. Ancak ülkelerin özelleştirme uygulamalarından beklentileri farklılık göstermektedir. Özelleştirmeler gelişmiş ülkeler için ekonominin rekabet gücünü ve verimliliğini artırmanın bir yolu olarak değerlendirilirken, gelişmekte olan ülkeler özelleştirme uygulamalarını, zarar eden KiT’lerin kamu bütçesine getirdikleri yükleri azaltma fırsatı ve finansal darboğazlardan çıkmak için bir gelir kaynağı olarak görmüştür.

Türkiye özelleştirme uygulamalarına dünyada ilk başlayan ülkelerden biri olmasına rağmen, özelleştirme programının oldukça yavaş yürütülmesi ve halen çok sayıda Kiт'in özelleştirme kapsamına alınmamış olması nedeniyle, kamunun ekonomideki ağırlığı geçmişe göre azalmış da olsa devam etmektedir. Makroekonomik krizler, zayıf koalisyon hükümetlerinin yol açtığı siyasi istikrarsızlık ve yasal ve idari yapılanmaya yönelik sorunlar, özelleştirme programının planlanan şekilde yürütülmesine mani olmuştur.

Özelleştirmelere yönelik genel uygulama, özelleştirilmesine karar verilen bir kamu teşebbüsünün, yeniden yapılandırma yoluyla bazı finansal ve operasyonel parametrelerini iyileştirdikten sonra özelleştirilmesi şeklindedir. Oysa ülkemizde geçmiş uygulamalara bakıldığında, özelleştirme programı kapsamına alınan kamu teşebbüslerinin özelleştirilmeden uzun süre kapsamda kaldıkları görülmektedir ${ }^{3}$. Çarpıcı bir örnek vermek gerekirse, Türk Hava Yolları Anonim Ortaklığı 1990 yılında özelleştirme programı kapsamına alınmış olmasına rağmen, hisselerinin \%50'den fazlasının özel sektöre geçişi ancak 2005 yılında sonuçlanabilmiştir. Kamu teşebbüslerinin özelleştirme programında bu kadar uzun süre bekletilmeleri, diğer ülkelerde uygulanan özelleştirme programlarında pek sık görülmeyen ve gerek ekonomik, gerekse de finansal olarak incelenmesi gereken bir durumu ortaya çıkarmaktadır ${ }^{4}$.

Özelleştirme literatürü geleneksel olarak, özel sektör sahipliğinin neden olduğu performans değişimlerine odaklanmıştır. Bu çalışmaların önemli bir kısmı, kamu teşebbüslerinin özelleştirme sonrası dönemde gösterdikleri finansal performansı özelleştirme öncesi dönem ile mukayese etmektedir (Megginson vd., 1994; Boubakri ve Cosset, 1998; D'souza ve Megginson, 1999; Boubakri vd., 2005; Aussenegg ve Jelic, 2007; Mathur ve Banchuenvijit, 2007). Diğer grup çalışmalar ise, özel teşebbüsler ile kamu teşebbüslerinin performanslarını karşılaştırarak, özel sektör sahipliği ile kamu sahipliği arasında performans açısından bir farklılık olup olmadığı sorusuna cevap aramaktadır (Feng vd., 2004). Literatürün yoğunlaştığı bu performans karşılaştırmalarının aksine bu çalışma özelleştirme öncesi dönemdeki performans değişimlerini ele almaktadır. Cevap aranan ilk soru, hangi finansal özelliklere sahip KiT’lerin özelleştirme programı kapsamına alındığıdır. Çalışmanın ikinci aşamasında ise, özelleştirme programına dahil edilen KiT’lerin kapsama alınmayı takip eden dönemde yeniden yapılandırmaya gidilip gitmedikleri ve bu teşebbüslerin özelleştirmeye doğru şekilde hazırlanıp hazırlanmadıkları analiz edilmektedir.

Çalışmanın sonuçları, iktidarların özelleştirilmeleri daha kolay olan Kiт’leri özelleştirme programı kapsamına almayı tercih ettiklerini göstermektedir. Çalışmanın diğer bir sonucu, özelleştirme programı kapsamına alınan KiT’lerde özellikle kapsama alınmayı takip eden ilk sene içinde çeşitli yeniden yapılandırma faaliyetleri yürütülmüş olduğudur. Bu makale beş bölümden oluşmaktadır. i̇kinci bölümde, konuyla ilgili geçmişte yapılan çalışmaların sonuçları özetlenecektir. Üçüncü bölümde, analizlerde uygulanan metodoloji ve kullanılan veri seti izah edilmektedir. Dördüncü bölüm analiz sonuçlarına yer verirken, son bölüm sonuç ve politika tartışmalarından oluşmaktadır. 


\section{Literatür Taraması}

Bu çalışma bir taraftan KiT’lerin nasıl bir sıralamayla özelleştirme programı kapsamına alındıkları incelerken, diğer taraftan da kapsama alınan KiT’lerin nasıl bir yeniden yapılandırmadan geçtiklerini analiz etmektedir.

Kamu teşebbüslerinin nasıl bir sıralamayla özelleştirilmesi gerektiği ile ilgili olarak, Maciaszek-Roberts (1993) Doğu Avrupa ülkeleri üzerine yaptığı hesaplanabilir genel denge modeline dayanan çalışmasında, ara malı üreten kamu teşebbüslerinin öncelikli olarak özelleştirilmesi durumunda ekonominin genelinin daha çok fayda sağlayacağını, nihai ürün üreten kamu teşebbüslerinin ilk olarak özelleştirilmesinden ise hane halkının daha çok faydalanacağını göstermiştir. Roland (1993) istihdam artışına neden olacak özelleştirmelerin bir an önce tamamlanması, sosyal açıdan gerilimlere ve işten çıkarmalara neden olacak özelleştirmelerin ise zamana yayılması gerektiğinin altını çizerek, bu durumun büyüme imkanı yüksek ve yeniden yapılandırma ihtiyacı düşük kamu teşebbüslerinin öncelikli olarak özelleştirilmelerinin nedeni olduğu belirtmektedir. Yine Roland (1994) benzer bir çalışmada en iyi performans sergileyen kamu teşebbüslerinin en önce özelleştirilmelerini önermektedir. 1987-1993 dönemi boyunca Hindistan'daki 25 kamu teşebbüsü verilerini kullanarak yaptıkları analizlerinde, Ahuj ve Majumdar (1998) verimsiz teşebbüslerin verimli teşebbüslerden önce özelleştirilmelerinin ekonomik açıdan daha uygun bir yol olduğunu göstermiştir. Gupta vd. (2008), Çek Cumhuriyetinde özelleştirilen 1121 kamu işletmesi verisi kullanarak yaptıkları analizlerde, Çek hükümetlerinin daha kârlı işletmeleri daha önce özelleştirdiklerini ortaya koymaktadır.

Literatürdeki ilgili çalışmaların büyük bir kısmı, özelleştirme süreçlerinde kamu teşebbüslerini yeniden yapılandırmanın faydalarını ortaya koymaktadır. Polonya'daki 75 kamu teşebbüsü yöneticilerinin katılımıyla uygulanan bir anket çalışmasının sonuçlarına göre, ankete katılan yöneticilerin tümü özelleştirme öncesinde yeniden yapılandırmanın gerekli olduğu görüşündedir (Pinto vd., 1993). Kikeri (1997) ihtiyaç fazlası istihdamın düşük seviyede olduğu durumlarda yeniden yapılandırmayı özelleştirme sonrası alıcıya bırakılmasının daha iyi sonuçlar vereceğini altını çizmektedir. Bös (1999) teorik çalışmasında yeniden yapılandırmanın başarılı sonuç verebilmesi için yapılandırmanın ya özelleştirme sonrası alıcı tarafından, ya da gelir maksimizasyonu hedefiyle hareket eden bir özelleştirme idaresi tarafından yürütülmesi gerektiğini ifade etmektedir. Norbäck ve Persson (2005) teorik çalışmalarında, özelleştirilecek kamu teşebbüslerinde kamu tarafından hayata geçirilecek yeniden yapılandırmaların, özelleştirme sonrasında özel sektörce yapılacak bir yeniden yapılandırmaya göre kamu tarafından ekonomik açıdan daha fazla tercih edileceğini ispatlamaya çalışmıştır. Chong ve Galdo (2007), özelleştirme öncesi dönemde icra kurulu başkanını (CEO) değiştiren telekomünikasyon şirketlerinin performanslarında iyileşme olduğunu göstermiştir. García ve Ansón (2007) İspanya'da 1985-2000 döneminde özelleştirilen 117 şirket verisi kullanarak yaptıkları çalışmalarında, özelleştirme öncesi yeniden yapılandırmaya giden kamu teşebbüslerinin özelleştirme sonrası dönemde daha yüksek performans sergilediklerini göstermişlerdir. D'Souza vd. (2007) 1961-1999 döneminde 39 ülkede özelleştirilen 161 kamu teşebbüsü verilerini kullanarak yaptıkları analizlerinde, yeniden yapılandırılan teşebbüslerin, yeniden yapılandırmaya gitmeyenlere göre daha yüksek operasyonel verimlilik artışı yakaladığını ortaya koymuştur. Literatürdeki bazı çalışmalar ise kamu teşebbüslerinin özelleştirme kapsamına alınmasalar bile yeniden yapılandırmaya gittiklerinin altını çizmiştir (Pinto vd., 1993; Estrin vd., 1994; Carlin vd., 1995; Roland ve Sekkat, 2000).

Özelleştirme öncesi yeniden yapılandırma faaliyetlerine karşı çıkan çalışmalarda altı çizilen gerekçelerden biri, sendikaların hükümetler üzerindeki etkileri sebebiyle yeniden yapılandırmanın sonuç vermeme ihtimalinin yüksek olmasıdır (López-de-Silanes ve arkadaşları, 1997). Bunun yanında, López-deSilanes (1997) özelleştirme öncesi yapılan yeniden yapılandırmaların yüksek maliyetlerine dikkat çekerek, zaman kaybetmeden ve yeniden yapılandırmaya gitmeden özelleştirmenin daha doğru bir yol olacağını belirtmektedir. Diğer taraftan Haltiwanger ve Singh (1999) ve Rama (1999) çalışanlar bazında yapılacak bir özelleştirme öncesi yeniden yapılandırmada, kamunun daha verimli ve başarılı çalışanları işten çıkarması ihtimalini göz önüne alarak, bu işlemlerin özelleştirme sonrasında yönetimi devralacak özel girişimcilere bırakılmasının daha doğru olacağının altını çizmektedir. 


\section{Yöntem ve Veri Seti}

Çalışmada iki farklı soruya cevap aranmaktadır:

- Hangi özellikleri taşıyan KiT’ler özelleştirme programı kapsamına alınmaktadır?

- Özelleştirme programı kapsamına alınan KiT’lerde kapsama alınmayı izleyen dönemde yeniden yapılandırmaya gidilmekte midir?

Tablo 1. Özelleştirme Programındaki KiT'lerin Kapsama Alınma Kriterlerinin Analizinde Kullanılan Finansal ve Operasyonel Değişkenler

\begin{tabular}{|c|c|}
\hline \multicolumn{2}{|l|}{ Kârlılık Oranları } \\
\hline Satışların Kârlıı̆̆ı & (Net Kâr)/(Net Satışlar) \\
\hline Varlıkların Kârlııı̆ı & (Net Kâr)/(Toplam Varlıklar) \\
\hline Özsermaye Kârlıı̆̆ı & (Net Kâr)/(Özsermaye) \\
\hline \multicolumn{2}{|l|}{ Verimlilik Oranları } \\
\hline Satış Verimliliği & (Net Satışlar)/(Çalışan Sayısı) \\
\hline Gelir Verimliliği & (Net Kâr)/(Çalışan Sayısı) \\
\hline \multicolumn{2}{|l|}{ Yatırım Oranları } \\
\hline Yatııım Harcamalarının Satışlara Oranı & (Yatırım Harcamaları)/(Satışlar) \\
\hline Yatırım Harcamalarının Varlıklara Oranı & (Yatırım Harcamaları)/(Toplam Varlıklar) \\
\hline Yatırımların Gerçekleşme Oranı & (Yatırım Harcamaları)/(Yatıımlara Ayrılan Ödenek) \\
\hline \multicolumn{2}{|l|}{ Reel Satış } \\
\hline Reel Satışlar & (Net Satışlar)/(Enflasyon Endeksi) \\
\hline \multicolumn{2}{|l|}{ İstihdam } \\
\hline İstihdam & Toplam Çalışan Sayısı \\
\hline \multicolumn{2}{|l|}{ Kaldıraç Oranları } \\
\hline Toplam Yabancı Kaynakların Toplam Varlıklara Oranı & (Toplam Yabancı Kaynaklar)/(Toplam Varlıklar) \\
\hline Uzun Vadeli Yabancı Kaynakların Özsermayeye Oranı & (Uzun Vadeli Yabancı Kaynaklar)/(Özsermaye) \\
\hline \multicolumn{2}{|l|}{ Nakit Akımı } \\
\hline Nakit Akımı Oranı & (Net Kâr+Amortisman)/(Toplam Varlıklar) \\
\hline
\end{tabular}

Özelleştirme programı kapsamına alınan KiT’lerin genel özelliklerini belirlemek amacıyla, çeşitli finansal ve operasyonel performans kriterleri kullanılarak, bağımsız gruplar t-testi (unpaired t-test) metodu uygulanmıştır. Analizlerde kullanılan finansal ve operasyonel performans kriterleri, Boubakri ve Cosset (1998) ve D'Souza ve Megginson (1999) tarafından özelleştirmeler üzerine yapılan çalışmalardan derlenmiş olup, detaylı açıklamalarına Tablo 1'de yer verilmektedir.

Analiz kapsamında, hangi özellikleri taşıyan KiT’lerin özelleştirme programı kapsamına alındığını belirlemek amacıyla, iki farklı portföy oluşturulmuştur (Tablo 2). Oluşturulan 1 numaralı portföy (Portföy-1), o yıl özelleştirme programı kapsamına alınan KiT'lerden oluşmaktadır. Örnek vermek gerekirse, Tablo 2'de ikinci kolondaki Portföy-1 başlığı altında 1990 yılına karşılık gelen 2 rakamı, 1990 yılında özelleştirme programı kapsamına alınan PETLAS ve THY'yi ifade etmektedir. Portföy-2 ise, hem özelleştirme programı kapsamına alınmamış KiT'leri, hem de özelleştirme programı kapsamına alınmış KiT'lerin kapsama alınma yılı $t_{0}$ kabul edildiğinde kapsama alınmadan önceki 2. yıl $\left(t_{-2}\right)$, kapsama alınmadan bir önceki yıl $\left(t_{-1}\right)$, kapsama alınma yılı $\left(t_{0}\right)$, kapsama alınmayı takip eden ilk yıl $\left(t_{1}\right)$ ve kapsama alınmayı takip eden ikinci yıl $\left(t_{2}\right)$ yıllarını kapsayan 5 yıllık dönem haricindeki verilerinden oluşmaktadır. Örneğin, 1999 yılında özelleştirme programı kapsamına alınan GERKONSAN 1999 yılı için Portföy-1'de yer alırken, 1997, 1998, 1999, 2000 ve 2001 yılları hariç diğer yıllarda Portföy-2 kapsamında yer almıştır. 
Tablo 2. Oluşturulan Portföylerdeki KiT’lerin Yıllara Göre Dağıımı

\begin{tabular}{|c|c|c|}
\hline Yıl & Portföy-1 & Portföy-2 \\
\hline 1990 & 2 & 40 \\
\hline 1992 & 4 & 32 \\
\hline 1993 & 7 & 34 \\
\hline 1994 & 1 & 34 \\
\hline 1997 & 1 & 41 \\
\hline 1998 & 8 & 34 \\
\hline 1999 & 1 & 31 \\
\hline 2000 & 1 & 29 \\
\hline 2001 & 2 & 36 \\
\hline Toplam & 27 & 311 \\
\hline
\end{tabular}

Bağımsız gruplar t-testi için ilk olarak, Tablo 1'de yer alan her değişken her iki portföy için de hesaplanmıştır. Sonrasında ise, hem Portföy-1, hem de Portföy-2'de yer alan değişkenlerin her biri için portföy bazında örneklem ortalamaları, örneklemlerin standart sapmaları ve ilgili t-istatistikleri hesaplanmıştır. Tablo 6, analizlerin sonuçlarını göstermektedir.

Analizlerin ikinci kısmında, özelleştirme programı kapsamına alınan KiT’lerde yeniden yapılanmaya gidilip gidilmediği incelenmiştir. Diğer ülkelerdeki geçmiş uygulamalara bakıldığında, bazı ülkelerin özelleştirilecek kamu teşebbüslerini özel sektöre devretmeden önce yeniden yapılandırdıkları, özellikle kitle özelleştirme yöntemini benimseyen ülkelerin ise KiT’leri yeniden yapılandırmadan özelleştirdikleri görülmektedir.

Yeniden yapılandırma kapsamında atılan adımlara bakıldığında, bazı hükümetlerin borç seviyeleri yüksek kamu teşebbüslerinin kamuya olan borçlarını silerek veya sermayelerini artırarak finansal kaldıraç oranlarını düşürmeye çalıştıkları görülmektedir. Bazı hükümetler ise, özelleştirme öncesi dönemde işgücü sayısını azaltarak bu kamu teşebbüslerini özel sektör açısından daha cazip hale getirmeye çalışmıştır. Özelleştirme öncesi atılan diğer bir adım da, teşebbüsün aktifinde bulunan atıl varlıkları elden çıkararak veya teşebbüsün yatırım yapması durumunda değerinin artacağı alanlarda yatırım yaparak teşebbüsün özel sektör için cazibesini artırmayı denemektir.

Özelleştirme programı kapsamına alınan KiT’lerin bu dönemde yeniden yapılandırmaya gidip gitmediklerini incelemek amacıyla oluşturulacak modelde, Tablo 3'de açıklanan çeşitli finansal ve operasyonel oranlarda kapsama alınma sonrasında nasıl bir değişiklik olduğu ve kapsama alınmayan KiT’lere göre bu oranların nasıl değişiklik gösterdiği analiz edilecektir. Tablo 3'de yer alan değişkenler, literatürde sıkça kullanılan değişkenler olup, Boubakri ve Cosset (1998) ve D'Souza ve Megginson (1999) tarafından yapılan analizlerde kullanılan değişkenler baz alınarak derlenmiştir.

Ancak bu oranlar arasından, literatürde finansal, organizasyonel ve stratejik yeniden yapılanmayı ifade eden 3 temel yeniden yapılanma kriteri üzerinde özellikle durulacaktır:

- Finansal Yeniden Yapılanma: Kaldıraç oranlarındaki değişim

- Organizasyonel Yeniden Yapılanma: Personel sayısındaki değişim

- Stratejik Yeniden Yapılanma: Yatırımlar ve toplam varlıklardaki değişim

Yapılacak analizlerde, özelleştirme kapsamına alınmayı takip eden 2 yıllık dönemde yeniden yapılandırmaya gidip gitmedikleri test edilecektir. Özelleştirme programı kapsamına alınma yılı $t_{0}$ olmak üzere, kapsama alınmayı takip eden ilk $\left(t_{1}\right)$ ve ikinci yılda $\left(t_{2}\right) t_{0}$ yılına göre bazı performans değişkenlerinde nasıl değişimler yaşandığı araştırılacaktır. Analizlerde kullanılan parametreler Tablo 4'de gösterilmiştir. Analizlerde KiT'ler; özelleştirme programı kapsamına alınmayan KiT'ler (Grup-1) ve kapsama alınan KiT'ler (Grup-2) olmak üzere iki gruba ayrılmıştır. $t_{0}$ - $_{1}$ dönemi için Grup-1'de 287, Grup-2'de 25 gözlem bulunmakta iken, t2-t0 dönemi için Grup-1'de 272, Grup-2'de 22 gözlem mevcuttur (Tablo 4). 
Özelleştirme Öncesi Yeniden Yapılandırma: Türk Kamu iktisadi Teşebbüsleri Üzerine Bir İnceleme

Tablo 3. Çeşitli Parametrelerin Değişimi Analizinde Kullanılan Değişkenler

\begin{tabular}{|c|c|}
\hline Değişken & Kısaltması \\
\hline (satışların maliyeti ${ }_{1,2}$-satışların maliyetio)/[(toplam varlıklaro)(\% GSYiH büyümesi)] & $\Delta \mathrm{SM}$ \\
\hline (faaliyet kârı ${ }_{1,2}$-faaliyet kârı) / [(toplam varlıklaro)(\% GSYiH büyümesi)] & $\Delta \mathrm{FK}$ \\
\hline (dönem kârı, ${ }_{1,2}$-dönem kârı) / [(toplam varlıklar 0$)(\%$ GSYiH büyümesi)] & $\Delta \mathrm{DK}$ \\
\hline (dönem net kârı $I_{1,2}$-dönem net kârı)/[((toplam varlıklar 0 )(\% GSYiH büyümesi)] & $\triangle N D K$ \\
\hline (toplam varıklar ${ }_{1,2}$-toplam varlıklar 0$) /$ [(toplam varlıklaro)(\% GSYiH büyümesi)] & $\Delta \mathrm{V}$ \\
\hline (özsermaye ${ }_{1,2}$-özsermaye 0$) /[($ toplam varlıklar 0$)(\%$ GSYiH büyümesi)] & $\Delta O ̈$ \\
\hline $\begin{array}{l}\left.\text { (uzun vadeli yabancı kaynaklar }{ }_{1,2} \text {-uzun vadeli yabancı kaynaklar } 0\right) /\left[\left(\text { toplam varlıklar }_{0}\right)(\% \text { GSYiH }\right. \\
\text { büyümesi)] }\end{array}$ & $\triangle$ UVYK \\
\hline (çalışan sayısı ${ }_{1,2}$-çalışan sayısıo)/(çalışan sayısı) & $\Delta C ̧$ \\
\hline (finansman giderleri $i_{1,2}$-finansman giderleri $)$ /[(toplam varlıklar 0 )(\% GSYiH büyümesi)] & $\Delta \mathrm{FG}$ \\
\hline (yatırım 1,2 -yatırımo)/[(toplam varlıklar 0$)(\%$ GSYiH büyümesi)] & $\Delta \mathrm{Y}$ \\
\hline (yatırım gerçekleşme oranı, ${ }_{1,2}$-yatırım gerçekleşme oranı)/(yatırım gerçekleşme oranı) & $\Delta \mathrm{YGO}$ \\
\hline (satış verimliliği $i_{1,2}$-satış verimliliği $\left.i_{0}\right) /\left(\right.$ satış verimliliği $\left.{ }_{0}\right)$ & $\Delta S V$ \\
\hline (net gelir verimliliğ $i_{1,2}$-net gelir verimliliğ $\mathrm{i}_{0}$ )/(net gelir verimliliği $\mathrm{i}_{0}$ ) & $\Delta \mathrm{NGV}$ \\
\hline $\begin{array}{l}\text { (yatııım harcamalarının satışlara oranı }{ }_{1,2} \text {-yatırım harcamalarının satışlara oranı) } /(\text { yatırım } \\
\text { harcamalarının satışlara oranı) }\end{array}$ & $\Delta(\mathrm{Y} / \mathrm{S})$ \\
\hline $\begin{array}{l}\text { (yatırım harcamalarının varlıklara oranı }{ }_{1,2} \text {-yatırım harcamalarının varlıklara oranı)/(yatırım } \\
\text { harcamalarının varlıklara oranı } \iota_{0} \text { ) }\end{array}$ & $\Delta(\mathrm{Y} / \mathrm{V})$ \\
\hline 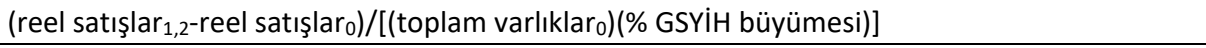 & $\Delta \mathrm{RS}$ \\
\hline $\begin{array}{l}\text { (yabancı kaynakların varlıklara oranı }{ }_{1,2}-\text { yabancı kaynakların varlıklara oranı } \iota_{0} /(\text { yabancı } \\
\text { kaynakların varlıklara oranı) }\end{array}$ & $\Delta(\mathrm{YK} / \mathrm{V})$ \\
\hline $\begin{array}{l}\text { (uzun vadeli yabancı kaynakların özsermayeye oranı } \mathbf{1}_{1,2} \text { - uzun vadeli yabancı kaynakların } \\
\text { özsermayeye oranı)/(uzun vadeli yabancı kaynakların özsermayeye oranı) }\end{array}$ & $\Delta($ UVYK/Ö) \\
\hline
\end{tabular}

Tablo 4. Grup-1 ve Grup-2'nin Gözlem Sayıları

\begin{tabular}{|c|c|c|}
\hline & Grup-1 & Grup-2 \\
\hline $\mathrm{t}_{0}-\mathrm{t}_{1}$ Dönemi & 287 & 25 \\
\hline $\mathrm{t}_{0}-\mathrm{t}_{2}$ Dönemi & 272 & 22 \\
\hline
\end{tabular}

Analizlerde ilk olarak, hem $t_{0}-t_{1}$ dönemi, hem de $t_{0}-t_{2}$ dönemi için her bir değişken bazında $t$ istatistikleri hesaplanmıştır. Sonrasında ise, gruplardaki parametrelerin varyanslarından yola çıkılarak ki-kare istatistikleri hesaplanmıştır. $t_{0}-t_{1}$ dönemi için yapılan analizlerin sonuçları Tablo 7 'de, $t_{0}-t_{2}$ dönemi için yapılan analizlerin sonuçları ise Tablo 8'de gösterilmiştir.

Çalışmada gerekli verileri elde etmek için, Sayıştay Başkanlığı ${ }^{5}$ (SB) tarafından her yıl hazırlanan ve SB arşivinden ulaşılan denetim raporlarından faydalanılmıştır. Her denetim raporunun sonunda, denetlenen KiT'in o yıla ait finansal tabloları yer almakta olup, analizlerde kullanılan finansal parametreler bu finansal tablolar arasında yer alan bilanço ve gelir tablolarından derlenmiştir. Bu finansal tablolar yanında, her denetim raporunun başında, denetlenen KiT'e ait özet bir tablo yer almaktadır. Analizlerde kullanılan yatırım ve işgücü istatistikleri bu özet tablolar yardımıyla düzenlenmiştir. Analiz edilecek KiT’lerin seçiminde, Kamu Yatııım Programında yer alma kriteri baz alınmış ve 1990-2001 döneminde Kamu Yatırım Programında yer alan KiT'ler analizlere dahil edilmiştir6.

Kiт’lerin hangi yıllar arasında özelleştirme programı kapsamında kaldıkları (özelleştirme programı kapsamına alınma ve özelleştirme tarihleri) ise, Kiт’lerin internet sitelerinden, Özelleştirme idaresi Başkanlığının internet sitesinden ve SB denetim raporlarından derlenmiştir. SB tarafından yapılan denetim sonrası hazırlanan raporları mevzuat gereği yayınlanmayan Petrol Ofisi, Boru Hatları ile Petrol Taşıma A.Ş. (BOTAŞ) ve Türkiye Petrolleri Anonim Ortaklığı (TPAO) gibi KiT'lerin verilerine ulaşılamadığından bu KiT'ler çalışmaya dahil edilmemiştir. Diğer taraftan mali sektörde yer alan bankalara (Ziraat Bankası ve Halk Bankası gibi) ve sigorta şirketlerine (Ankara Anonim Türk Sigorta gibi) ait veriler, verilerin farklı karakterde 
düzenlenmiş olması nedeniyle analiz kapsamına alınmamıştır. SB arşivlerinden denetim raporuna ulaşılan KiT'lerin yıllara göre dağılımı Tablo 5 'de verilmiştir.

Tablo 5. Sayıştay Başkanlığı Denetim Raporlarına Ulaşılan KiT’lerin Yıllara Göre Dağılımı

\begin{tabular}{|c|c|c|c|}
\hline Yıl & $\begin{array}{c}\text { Özelleştirme Programı } \\
\text { Kapsamındaki KiT Sayısı }\end{array}$ & $\begin{array}{c}\text { Özelleştirme Programı Kapsamına } \\
\text { Alınmamış KiT Sayısı }\end{array}$ & Toplam \\
\hline 1990 & 10 & 38 & 48 \\
\hline 1991 & 8 & 38 & 46 \\
\hline 1992 & 7 & 39 & 46 \\
\hline 1993 & 18 & 28 & 46 \\
\hline 1994 & 18 & 30 & 48 \\
\hline 1995 & 15 & 28 & 43 \\
\hline 1996 & 15 & 30 & 45 \\
\hline 1997 & 21 & 31 & 52 \\
\hline 1998 & 21 & 24 & 45 \\
\hline 1999 & 18 & 25 & 43 \\
\hline 2000 & 17 & 23 & 40 \\
\hline 2001 & 20 & 21 & 41 \\
\hline Toplam & 188 & 355 & 543 \\
\hline
\end{tabular}

Yapılan çalışmalar neticesinde 664 adet SB raporuna ulaşılmasına rağmen, bu raporların hepsini kullanmak mümkün olamamıştır. Zira KiT’lerin özelleştirildikleri yıllar için hazırlanan denetim raporlarında bilanço ve gelir tablolarına yer verilmemiştir. Bazı KiT’ler ise yıl içerisinde yeniden yapılandırılarak birden fazla KiT'e bölünmüş olup (PTT'nin yeniden yapılanması ile kurulan Posta İşletmesi ve Türk Telekom; TEK'in yeniden yapılanması ile kurulan Türkiye Elektrik Dağıtım Anonim Şirketi (TEDAŞ) ve Türkiye Elektrik Iletim Anonim Şirketi (TEAŞ) gibi), bu durumlarda hazırlanan finansal tablolar tam bir seneyi kapsamadığı için analizlere dahil edilememiştir. Bu gibi eksik veriye sahip raporlar çıkarıldıktan sonra geriye analizlerde kullanılabilecek 650 adet rapor kalmıştır.

\section{Analizlerin Sonuçları}

Özelleştirme programı kapsamına alınan Kiт’lerin seçim kriterlerini belirlemek için yapılan analizlerin sonuçları Tablo 6'da gösterilmektedir.

Analizlerde Satışların Kârııı̆̆ı, Varlıkların Kârlılığı ve Özsermaye Kârlılığı olmak üzere üç adet kârlııık oranı kullanılmıştır. Tablo 6 'da yer alan sonuçlara göre, özelleştirme programı kapsamına o yıl alınan KiT'lerden meydana gelen Portföy-1'in ortalama kârlıık oranları satışların kârlılı̆ı, varlıkların kârlılığı ve özsermaye kârlılığı için sırasıyla -0,083, $-0,195$ ve 0,320 olarak gerçekleşirken, Portföy-2 için aynı ortalamalar sırasıyla -0,516, $-0,378$ ve 0,267 olarak hesaplanmıştır. Hesaplanan ilgili t-istatistikleri, iki portföyün kârlılık oranları arasında istatistiksel olarak anlamlı bir fark olmadığını göstermektedir. Satışların kârııı̆̆ı ve varlıkların kârlıı̆̆ı ortalamaları negatifken özsermaye kârlıı̆̆ı ortalamalarının pozitif bir değer almasının nedeni, bazı KiT’lerin negatif özsermayeye sahip olmasındadır. Tablo 6'da yer alan sonuçlar, istatistiksel olarak anlamlı olmamakla birlikte, özelleştirme programı kapsamına alınan KiT’lerin diğer KiT’lere göre daha az zarar ettiğini göstermektedir.

Verimlilik oranları açısında bakıldığında, özelleştirme programı kapsamına alınan KiT'ler kontrol portföydeki KiT’lere göre daha yüksek gelir verimliliği oranına sahipken, bu KiT'lerin satış verimliliği oranları nispeten daha düşüktür. t-testi sonuçlarına göre her iki portföy arasındaki fark istatistiksel olarak anlamlı değildir. 


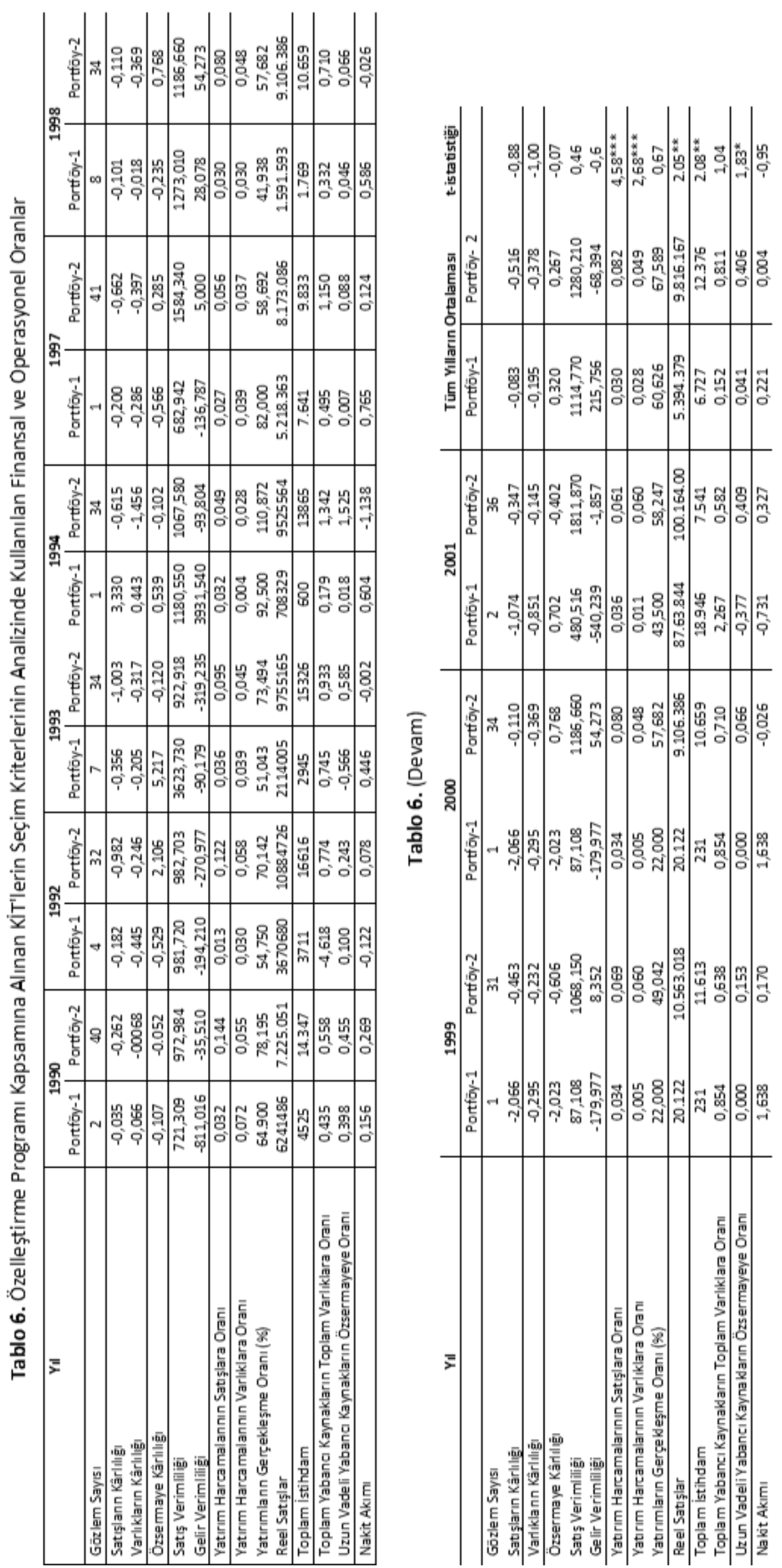


Yatırım performansı kapsamında yatırım harcamalarının satışlara oranı, yatıım harcamalarının varlıklara oranı ve yatıımların gerçekleşme oranı olmak üzere üç adet parametre kullanılmıştır. Yapılan hesaplamalar sonucunda, kontrol portföyünde yer alan KiT’lerin yatırım harcamalarının satışlara oranı ve yatırım harcamalarının varlıklara oranı, özelleştirme programı kapsamına alınan KiT’lerden oluşturulan portföy ortalamalarına göre daha yüksek olup, aradaki fark istatistiksel olarak anlamlıdır. Bu sonucu, yatırım intiyaçları nispeten daha düşük Kiт’lerin özelleştirme programı kapsamına alındığı şeklinde yorumlamak mümkündür. Bu sonuca paralel bir şekilde, özelleştirme programı kapsamına alınan KiT'lerde yatırım gerçekleşme oranının $(\% 60,63)$ kontrol portföye $(\% 67,59)$ göre daha düşük olmakla birlikte, bu sonuç istatistiksel olarak anlamlı çıkmamıştır.

Analizlerde KiT ölçeğini ölçmek amacıyla reel satışlar ve toplam istihdam istatistikleri kullanılmıştır. Portföy-1'in ortalama reel satışı 9.816.167 TL olarak gerçekleşirken, Portföy-2'de yer alan KiT'lerin ortalama reel satışı 5.394.379 TL olarak gerçekleşmiştir. Aradaki fark istatistiksel olarak anlamlıdır. Benzer bir şekilde, Porföy-1 kapsamındaki Kiт'lerin ortalama istihdam sayısı (6.727), Portföy-2'ye (12.376) göre daha yüksektir ve aradaki fark istatistiksel olarak anlamlıdır. Buna göre, özelleştirme kapsamına alınan Kiт’ler istatistiksel olarak anlamlı bir şekilde daha düşük satış ve istihdam rakamlarına, dolayısıyla da daha düşük bir ölçeğe sahiptir

KiT’lerin borçluluk seviyelerini ölçmek amacıyla iki adet finansal kaldıraç oranı kullanılmıştır. Buna göre, özelleştirme programı kapsamına alınan Kiт’lerin borçluluk seviyelerinin diğer Kiт’lere göre daha düşük seviyelerde olduğu görülmektedir. Kapsama alınan Kiт’lerin yabancı kaynaklarının toplam varlıklarına oranı 0,152 , uzun vadeli yabancı kaynaklarının öz sermayelerine oranı 0,041 olarak hesaplanırken bu oranlar diğer KiT'ler için sırasıyla 0,811 ve 0,406 olarak hesaplanmıştır. Toplam yabancı kaynakların toplam varlıklara oranı açısından bakıldığında iki portföy arasındaki fark istatistiksel olarak anlamlı çıkmazken, her iki portföy arasındaki fark uzun vadeli yabancı kaynakların öz sermayeye oranı açısından istatistiksel olarak anlamlıdır.

Tablo 7. $t_{0}-t_{1}$ Döneminde KiT’lerin Çeşitli Parametrelerindeki Değişim

\begin{tabular}{|c|c|c|c|c|c|c|}
\hline \multirow[b]{2}{*}{ Değişken } & \multicolumn{2}{|c|}{ Grup-1 } & \multicolumn{2}{|c|}{ Grup-2 } & \multicolumn{2}{|c|}{ Test istatistikleri } \\
\hline & Ortalama & Medyan & Ortalama & Medyan & t-istatistiği & Ki-kare \\
\hline$\Delta \mathrm{SM}$ & 0.082 & 0,016 & 0.010 & 0,004 & 1.33 & 0,59 \\
\hline$\Delta \mathrm{FK}$ & -0.036 & 0 & $-0,017$ & $-0,009$ & -0.74 & $3,68^{*}$ \\
\hline$\Delta \mathrm{DK}$ & $-0,002$ & $-0,002$ & $-0,129$ & $-0,014$ & 1,20 & 1,63 \\
\hline$\triangle N D K$ & $-0,002$ & $-0,002$ & $-0,127$ & $-0,010$ & 1,18 & 1,55 \\
\hline$\Delta \mathrm{V}$ & 0,059 & 0,040 & 0,010 & $-0,054$ & 1,12 & $6,59 * *$ \\
\hline$\Delta O ̈$ & 0,062 & 0,008 & $-0,090$ & $-0,034$ & 1,22 & $3,44^{*}$ \\
\hline$\Delta$ UVYK & $-0,001$ & 0 & $-0,001$ & 0 & $-0,07$ & 0,54 \\
\hline$\Delta C ̧$ & 0,058 & $-0,036$ & $-0,114$ & $-0,091$ & $2,28 * *$ & 2,3 \\
\hline$\Delta \mathrm{FG}$ & 0,013 & 0 & 0,005 & 0,002 & 0,50 & 0,19 \\
\hline$\Delta \mathrm{Y}$ & 0 & 0 & 0,001 & 0 & 0,05 & 1,91 \\
\hline$\Delta Y G O$ & 1,410 & $-0,020$ & 13,809 & $-0,079$ & $-0,94$ & 0,06 \\
\hline$\Delta S V$ & 0,171 & $-0,009$ & 0,122 & $-0,008$ & 0,25 & 0 \\
\hline$\Delta N G V$ & 3,647 & $-0,189$ & $-0,043$ & 0,024 & 0,93 & 0,47 \\
\hline$\Delta(\mathrm{Y} / \mathrm{S})$ & 9916,550 & $-0,162$ & 0,743 & $-0,386$ & 1,04 & 1,47 \\
\hline$\Delta(\mathrm{Y} / \mathrm{V})$ & 8989,950 & $-0,159$ & 0,599 & $-0,392$ & 1,06 & 1,11 \\
\hline$\Delta \mathrm{RS}$ & 0,080 & 0 & $-0,032$ & $-0,003$ & $1,78^{*}$ & $3,50 *$ \\
\hline$\Delta(\mathrm{YK} / \mathrm{V})$ & 0,148 & 0,003 & 0,163 & $-0,146$ & $-0,05$ & $4,00 * *$ \\
\hline$\Delta$ (UVYK/Ö) & 155,900 & $-0,175$ & 46,245 & $-0,461$ & 1,05 & 1,51 \\
\hline
\end{tabular}


Özelleştirme Öncesi Yeniden Yapılandırma: Türk Kamu İktisadi Teşebbüsleri Üzerine Bir İnceleme

Tablo 8. $t_{0}-t_{2}$ Döneminde KiT’lerin Çeşitli Parametrelerindeki Değişim

\begin{tabular}{|c|c|c|c|c|c|c|}
\hline \multirow[b]{2}{*}{ Değişken } & \multicolumn{2}{|c|}{ Grup-1 } & \multicolumn{2}{|c|}{ Grup-2 } & \multicolumn{2}{|c|}{ Test istatistikleri } \\
\hline & Ortalama & Medyan & Ortalama & Medyan & t-istatistiği & Ki-kare \\
\hline$\Delta S M$ & 0,045 & 0,025 & 0,028 & 0,023 & 0,32 & 0,07 \\
\hline$\Delta \mathrm{FK}$ & $-0,010$ & 0,001 & 0,014 & 0,005 & $-1,95^{*}$ & 2,36 \\
\hline$\Delta \mathrm{DK}$ & 0,017 & 0,001 & 0,157 & $-0,004$ & $-1,13$ & 0,85 \\
\hline$\Delta N D K$ & 0,016 & 0,001 & 0,154 & $-0,003$ & $-1,12$ & 0,53 \\
\hline$\Delta \mathrm{V}$ & 0,051 & 0,067 & 0,017 & 0,055 & 0,90 & 0,25 \\
\hline$\Delta \ddot{~}$ & 0,007 & 0,016 & 0,232 & 0,036 & $-1,59$ & 2,42 \\
\hline$\Delta$ UVYK & 0,023 & 0 & 0,007 & 0 & 0,68 & 0,10 \\
\hline$\Delta C \zeta$ & 0,043 & $-0,077$ & $-0,068$ & 0,97 & $-0,86$ & 2,36 \\
\hline$\Delta \mathrm{FG}$ & 0 & 0 & $-0,151$ & 0 & 1,23 & 0,50 \\
\hline$\Delta \mathrm{Y}$ & 0 & 0 & 0,001 & 0 & $-1,78^{*}$ & 0,55 \\
\hline$\Delta Y G O$ & 2,759 & $-0,107$ & $-0,148$ & $-0,371$ & 1,37 & $6,14 * *$ \\
\hline$\Delta S V$ & 0,174 & $-0,026$ & 0,049 & $-0,083$ & 0,69 & 0,13 \\
\hline$\Delta N G V$ & 7,908 & $-0,257$ & 28,692 & 0,337 & $-0,74$ & 1,10 \\
\hline$\Delta(\mathrm{Y} / \mathrm{S})$ & 4761,480 & $-0,238$ & $-0,234$ & $-0,688$ & 1,07 & $6,97 * * *$ \\
\hline$\Delta(\mathrm{Y} / \mathrm{V})$ & 5983,370 & $-0,248$ & 0,649 & $-0,621$ & 1,07 & $4,22^{* *}$ \\
\hline$\Delta \mathrm{RS}$ & 0,067 & 0 & 0,077 & 0 & $-0,11$ & 0,54 \\
\hline$\Delta(\mathrm{YK} / \mathrm{V})$ & 0,222 & $-0,034$ & 0,370 & $-0,140$ & $-0,42$ & 1,01 \\
\hline$\Delta($ UVYK/Ö) & 269,688 & $-0,419$ & 1,632 & $-0,647$ & $1,92 *$ & 0,95 \\
\hline
\end{tabular}

***, **, * t-istatistiği ile ki-kare istatistiğinin sırasıyla \%1, \%5 ve \%10 seviyelerinde anlamlı olduğunu göstermektedir.

Son olarak her iki portföyün nakit akımları mukayese edilmiş olup, Portföy-2'nin nakit akımları, Portföy-1'e göre yüksek olmasına rağmen aradaki fark istatistiksel olarak anlamlı çıkmamıştır.

Analizlerin ikinci kısmında, özelleştirme programı kapsamına alınan KiT'lerde kapsama alınmayı izleyen dönemde yeniden yapılandırmaya gidilip gidilmediği test edilecektir. Tablo $7 t_{0} t_{1}$ döneminde bazı parametrelerde yaşanan değişimleri göstermektedir. Buna göre, kârlılık açısından bakıldığında, $t_{0}-t_{1}$ döneminde özelleştirme programı kapsamına alınmayı takip eden ilk yıldaki KiT’lerden oluşan Grup-2'nin faaliyet kârlıığı düşerken kontrol grubunun (Grup-1) faaliyet kârlılığı değişmemiştir.

Tablo 7'de istatistiksel olarak anlamlı çıkan sonuçlara (t-istatistiği açısından) bakıldığında, kapsama alınan KiT'lerin takip eden ilk yılda çalışan sayısında azaltmaya gittiği, buna karşın kontrol gruptaki kiT'lerin aynı dönemde az da olsa istihdam artışına gittikleri görülmektedir. Bu mukayeseden, kapsama alınan Kiт’lerin çalışan sayılarını azaltarak bir yeniden yapılandırmaya gittiklerini söylemek mümkündür. Benzer bir şekilde, Grup-2'de yer alan KiT'lerin satış rakamları düşerken, kontrol gruptaki KiT'lerin satışları artmıştır ve bu fark istatistiksel olarak anlamlıdır. Bu sonucu ise, çalışan sayısındaki azalma düşünüldüğünde beklenebilir olarak tanımlamak mümkündür. Zira çalışan sayısındaki azalmanın kapsama alınan KiT’lerin satışlarını olumsuz etkilemesi olağandır.

Tablo 7'deki Ki-Kare istatistiklerine bakıldığında, faaliyet kârlılığındaki, toplam varlıklardaki, öz sermayedeki, reel satıların toplam varlıklara oranındaki ve yabancı kaynakların varlıklara oranındaki değişimler her iki grup için farklılık göstermektedir. Buna göre, kapsama alınan Kiт’ler kapsama alınmayı takip eden ilk yıl içinde Grup-1'de yer alan KiT’lere göre daha az bir faaliyet kârlılığı düşüşü yaşamışlar, varlıklarını daha az artırmışlar, öz sermayelerini düşürmüşler, satışlarında düşüş yaşamışlar ve kaldıraç oranlarını artırmışlardır. Bu değişimlerden finansal kaldıraçtaki görece daha yüksek artışı hariç tutarsak, diğer parametrelerdeki değişim literatürde incelenen temel yeniden yapılandırma girişimleri ile paralellik göstermektedir. 
Tablo $8 \quad t_{0}-t_{2}$ döneminde bir takım finansal ve operasyonel değişkenlerdeki değişimleri göstermektedir. Analizlerde istatistiksel olarak anlamlı çıkan sonuçlardan ilki (t-istatistiği açısından), faaliyet kârlılığıdır. Kapsama alınmayı izleyen ikinci yılda, bir önceki yıldaki görece daha iyi karlılık performansı devam etmektedir. Buna göre, kapsama alınan KiT’lerin faaliyet kârlılı̆ı iki yıllık dönemde 0,014 oranında artarken diğer KiT’lerin faaliyet kârlılığı aynı dönemde 0,01 oranında düşmüştür. Benzer bir şekilde kapsama alınan KiT'lerde, kapsama alınmayı izleyen iki yıllık dönemde yatırımların toplam varlıklar oranı 0,001 oranında artış gösterirken kontrol grubu oluşturan kiT’lerde bu oran iki yıllık dönemde herhangi bir değişiklik göstermemiştir. Finansal kaldıraç açısından bakıldığında, kapsama alınan KiT'lerin izleyen iki yıllık dönemde borçluluk oranlarını, kontrol grupta yer alan KiT’lere göre çok daha düşük bir oranda artırdıkları görülmektedir. Tablo 8'de yer alan Ki-kare istatistiklerine bakıldığında, kapsama alınan KiT'lerde öngörülen yatırımların istatistiksel olarak anlamlı bir şekilde hayata geçirilmediği görülmektedir. Bu sonuçla uyumlu bir şekilde, yatırımların satışlara oranında istatistiksel olarak anlamlı bir düşüş yaşanmıştır. Son olarak da, yatırımların varlıklara oranında, kapsama alınan KiT’lerde kontrol grupta yer alan KiT’lere göre daha düşük bir artış yaşanmış olup, bu sonuç da yine istatistiksel olarak anlamlıdır. Yatırımlarla ilgili bu parametrelere bakıldığında, özelleştirme programı kapsamına alınan KiT’lerde kapsama alınmayı takip eden ilk iki yıllık dönemde yatırımların frenlendiği görülmektedir. Bu sonuç, devletin özelleşecek kiT’lere daha fazla para harcamak istememesi şeklinde yorumlanabileceği gibi, yatırım kararlarını özelleştirme sonrasına bırakarak yeni sahiplere stratejik kararlarda hareket imkanı sağlanması yönünde bir yorum getirmek de mümkündür.

\section{Sonuç ve Değerlendirme}

Bu çalışmada, 1990-2001 döneminde hangi özellikleri taşıyan KiT’lerin özelleştirme programı kapsamına alındıkları ve kapsama alınmayı takip eden dönemde herhangi bir yeniden yapılandırmaya gidilip gidilmediği analiz edilmiştir. Bu çalışma özelleştirmede yeniden yapılandırma konusunu çeşitli finansal ve operasyonel performans kriterleri kullanılarak, bağımsız gruplar t-testi (unpaired t-test) metodu ile analiz etmesi açısından orjinallik taşımaktadır.

İstatistiksel olarak anlamlı sonuçlara bakıldı̆̆ında, özelleştirme programı kapsamına alınan KiT’lerin diğer Kiт’lere göre daha düşük yatırım harcamalarının satışlara oranına ve yatırım harcamalarının varlıklara oranına sahip oldukları görülmektedir. Bu sonucu, yatırım ihtiyaçları daha düşük seviyede olan KiT’lerin öncelikli olarak özelleştirme programı kapsamına alındığı şeklinde yorumlamak mümkündür.

Diğer taraftan kapsama alınan KiT’lerin ölçeklerini gösteren reel satışlar ve toplam istihdam istatistikleri incelendiğinde, özelleştirilmesine karar verilen KiT’lerin daha düşük reel satışlara ve istihdam seviyelerine sahip olduğu görülmekte olup, bu sonuç istatistiksel olarak anlamlıdır. İstatistiksel olarak anlamlı çıkan diğer bir fark, finansal kaldıraçla ilgilidir. Buna göre kapsama alınan KiT’ler istatistiksel olarak anlamlı bir şekilde daha düşük borç seviyelerine sahiptir.

Kapsama alınan KiT’lerden meydana gelen portföyün ortalama kârlıık ve verimlilik oranları kontrol portföyüne göre daha yüksek çıkmış olmasına rağmen bu sonuç istatistiksel olarak anlamlı değildir. Kârlı KiT'lerin öncelikli olarak özelleştirme programı kapsamına alınmaları ise, KiT'lerdeki düşük operasyonel ve finansal verimliliği özelleştirme yoluyla iyileştirme amacını ikinci plana iterek, kolaylıkla özelleştirilebilecek kârlı KiT'lere öncelik verildiğini ve özelleştirmelerdeki temel amacın özelleştirme geliri elde etmek olduğunu ortaya koymaktadır. Bu değerlendirme, ülkemizdeki özelleştirme politikalarına yöneltilen ve özelleştirme uygulamalarının gelir elde etme amacına odaklandığı yönündeki genel eleştirileri destekler niteliktedir. İstatistiksel olarak desteklenmemekle birlikte, daha verimli ve kârlı KiT'lerin daha önce özelleştirme programı kapsamına alınması, Saygılı ve Taymaz'ın (2001) Türk çimento fabrikalarının özelleştirilmelerine yönelik yaptıkları ve özelleştirmede önceliğin en verimli çalışan fabrikalara verildiğini ortaya koyan çalışmayı destekler niteliktedir.

Analizlerin sonuçları, yatırım intiyaçları, reel satışları, personel sayıları ve kaldıraç oranları nispeten daha düşük seviyede olan KiT'lerin özelleştirme programı kapsamına diğer KiT'lere göre daha önce alındığını göstermektedir. Bu sonucu hükümetlerin, yatırım ihtiyaçları ve kaldıraç oranları düşük olması nedeniyle özel sektörün özelleştirme ihalelerinde daha fazla ilgi göstermesi muhtemel kiт’leri öncelikli olarak özelleştirme 
programı kapsamına dahil ettiği şeklinde yorumlamak mümkündür. Nitekim bu sonuç, Biglaiser ve Brown'un (2003) bulgularıyla da paralellik göstermektedir. Biglaiser ve Brown (2003) Latin Amerika ülkeleri verilerini kullanarak yaptıkları analizlerinde, kamu teşebbüslerinin borç stoklarının yüksek olduğu durumlarda daha az özelleştirme yapılmasını, özel sektörün borçlu kamu teşebbüslerini satın almak istememelerine bağlamaktadır. Bu özellikteki kiT’lerin öncelikli olarak özelleştirilmeleri, özelleştirme ihalelerinde sonuç alınması ve özelleştirme programının sağlıklı olarak devam edebilmesi açısından da önemlidir. Personel sayısı düşük olan KiT'lerin öncelikli olarak kapsama alınmaları, bu KiT'lerin özelleştirilmesinin siyasi maliyetlerinin personel sayıları ile orantılı şekilde nispeten daha düşük olması nedeniyle anlamlıdır. Siyasi otorite, işten çıkarmalar nedeniyle gelebilecek eleştirilerin şiddetini azaltabilmek için, özelleştirme programı kapsamına ilk aşamada daha küçük ölçekli KiT’leri almayı tercih etmiştir ve bu sonuç literatürle de uyuşmaktadır. Diğer taraftan daha kârı Kiт’lerin özelleştirme programı kapsamına alınmasının olası başka bir nedeni, bu tür KiT'lerin halka arz yoluyla özelleştirilmelerinin daha kolay olmasıdır. Zira halka araz yoluyla özelleştirmeler Özelleştirme Ana Planında ifade edilen amaçlardan 4. öncelikli amaç olan "halka açık şirketlerin teşvik edilmesi" ve 5. sırada yer alan "sermaye piyasalarının geliştirilmesinin hızlandırılması" amaçlarıyla uyumludur.

Yeniden yapılandırma açısından bakıldığında ise, özelleştirme programı kapsamına alınan Kiт’lerin kapsama alındıktan sonraki ilk yılda ciddi bir yeniden yapılandırmaya gittiği, ancak bu yeniden yapılandırma çabalarının bir sonraki yıl etkisini kaybettiği görülmektedir. Kapsama alınan KiT’ler, kapsama alınmayı izleyen ilk yılda çalışan sayısında ve toplam varlıklarda azalmaya gitmişler, yabancı kaynakların varlıklara oranını düşürmüşlerdir. Bu açıdan bakıldığında, kapsama alınan KiT’lerin kendilerini hızla özelleştirmeye hazırlamışladır. Ancak aynı dönemde dikkat çekici diğer bir sonuç özsermayede ve reel satışlarda azalış yaşanmasıdır. Muhtemelen KiT'lerin atıl veya verimsiz durumdaki varlıklarını elden çıkarmaları reel satışları da olumsuz etkilemiştir. Tespit edilen ilginç bir sonuç, yatırımların satışlara ve varlıklara oranlarında azalış görülürken yatırımın bizzat kendisinde çok küçük de olsa bir artış gözlenmesidir. Bu durum, satışların ve varlıkların, yatııımlara göre daha hızlı azaldığını göstermektedir.

Yeniden yapılandırmaların kiт’lerin özelleştirme değerleri ve özelleştirme sonrası uzun vadeli performansları üzerindeki etkisi bu çalışmayı tamamlayacak bir araştırma konusu olacaktır.

\section{Son Notlar}

1. Bu makale yazarın "Özelleştirmeye Hazırlanan Kamu iktisadi Teşebbüslerinin Analizi" başlıklı doktora tezinden üretilmiştir.

2. Bu çalışma, 28-29-30 Kasım 2018 tarihlerinde düzenlenen "IV. International Conference on Applied Economics and Finance \& Extended with Social Sciences (ICOAEF'18)" kongresinde sözlü olarak sunulmuş ve öz kısmı Bildiri Özetleri Kitabında yayınlanmıştır.

3. Literatürde, ülkelerin özelleştirme hızlarını mukayese eden genel bir çalışma mevcut olmamasına rağmen, Polonya (Blaszczyk vd., 1999) ve Romanya'nın (Tache, 2008) özelleştirme tecrübelerine bakıldığında, bu ülkelerin özelleştirme uygulamalarında Türkiye'ye göre daha hızlı ilerlediği görülmektedir. Romanya'nın Türkiye'ye göre daha hızlı ilerleyen özelleştirme programı, yavaş ilerlediği gerekçesiyle başka bir çalışmanın da konusu olmuştur (McCollum ve Schoening, 2002).

4. Türkiye'de özelleştirmelerde yaşanan gecikmenin bir sebebi de uygulanan özelleş̧irme yöntemleri ile ilgilidir. ülkemizde en sık tercih edilen özelleştirme yöntemi olan doğrudan satışlar, daha yüksek özelleştirme geliri elde edilmesine yardımcı olmasına rağmen, nispeten daha yavaş ilerleyen bir yöntemdir (Schusselbauer, 1999).

5. Geçmişte Yüksek Denetleme Kurulu tarafindan yerine getirilmekte olan KiT denetim faaliyetleri, 19.12.2010 tarih ve 6085 sayılı Kanun kapsamında Yüksek Denetleme Kurulunun Sayıştay Başkanlığı ile birleştirilmesi sonucunda Sayıştay Başkanlığı uhdesine geçmiştir.

6. Çalışmanın yapıldığı tarihte en güncel veriler 1990-2001 dönemine aittir. 


\section{Kaynaklar}

Ahuja, G., \& Majumdar, S. K. (1998). On the sequencing of privatization in transition economies. Industrial and Corporate Change, 7(1), 109-151.

Aussenegg, W., \& Jelic, R. (2007). The operating performance of newly privatised firms in Central European transition economies. European Financial Management, 13(5), 853-879.

Biglaiser, G., \& Brown, D. S. (2003). The determinants of privatization in Latin America. Political Research Quarterly, 56(1), 77-89.

Blaszczyk, B., Górzyñski, M., Kamiñski, T., Maliszewski, W., \& Woodward, R. (1999). Privatization and company restructuring in Poland.

Boubakri, N., \& Cosset, J. C. (1998). The financial and operating performance of newly privatized firms: Evidence from developing countries. The Journal of Finance, 53(3), 1081-1110.

Boubakri, N., Cosset, J. C., \& Guedhami, O. (2005). Liberalization, corporate governance and the performance of privatized firms in developing countries. Journal of Corporate Finance, 11(5), 767-790.

Bös, D. (1999). Privatization and restructuring: An incomplete-contract approach. Journal of Institutional and Theoretical Economics (JITE)/Zeitschrift für die gesamte Staatswissenschaft, 362-382.

Carlin, W., Reenen, J. V., \& Wolfe, T. (1995). Enterprise restructuring in early transition: the case study evidence from Central and Eastern Europe 1. Economics of Transition, 3(4), 427-458.

Chong, A., \& López-De-Sılanes, F. (2004) Privatization in Latin America: What Does the Evidence Say?, Economia, 4, 37111.

Chong, A., \& Galdo, V. (2007). Should state-owned firms change CEOs before privatization? Some evidence from the telecommunications industry. Applied Economics, 14, 591-595.

D'souza, J., \& Megginson, W. L. (1999). The financial and operating performance of privatized firms during the 1990 s. The Journal of Finance, 54(4), 1397-1438.

D'souza, J., Megginson, W., \& Nash, R. (2007) The effects of changes in corporate governance and restructurings on operating performance: Evidence from privatizations. Global Finance Journal, 18, 157-184.

Estrin, S., Gelb, A., \& Singh, I. (1994). Restructuring, viability and privatization: A comparative study of enterprise adjustment in transition. Paper presented at the World Bank Workshop on Enterprise Adjustment in Eastern Europe, September 22nd-23rd, Washington DC.

Feng, F., Sun, Q., \& Tong, W. H. (2004). Do government-linked companies underperform? Journal of Banking \& Finance, 28(10), 2461-2492.

García, L. C., \& Ansón, S. G. (2007). The Spanish privatisation process: Implications on the performance of divested firms. International Review of Financial Analysis, 16(4), 390-409.

Gupta, N., Ham, J. C., \& Svejnar, J. (2008). Priorities and sequencing in privatization: Evidence from Czech firm panel data. European Economic Review, 52(2), 183-208.

Haltiwanger, J., \& Singh, M. (1999). Cross-Country Evidence on Public Sector Retrenchment. The World Bank Economic Review, 23-66.

Kikeri S. Privatization and Labor: What Happens to Workers when Governments Divest?, Worldbank Technical Paper No.396, 1997.

López-de-Silanes, F. (1997). Determinants of privatization prices. The Quarterly Journal of Economics, 112(4), 965-1025.

López-de-Silanes, F., Shleifer, A., \& Vishny, R. W. (1997). Privatization in the United States. RAND Journal of Economics, 28(3), 447-471.

Maciaszek-Roberts, B. (1993). Transition in eastern Europe: Does the sequence of privatization matter? Journal of International Development, 5(2), 113-121.

Mathur, I., \& Banchuenvijit, W. (2007). The effects of privatization on the performance of newly privatized firms in emerging markets. Emerging Markets Review, 8(2), 134-146.

McCollum, J. K., \& Schoening, N. C. (2002). Romania: A case study in delayed privatization. International Journal of Public Administration, 25(9-10), 1221-1234.

Megginson, W. L., Nash, R. C., \& Van Randenborgh, M. (1994). The financial and operating performance of newly privatized firms: An international empirical analysis. The Journal of Finance, 49(2), 403-452.

Norbäck, P. J., \& Persson, L. (2005). Privatization and restructuring in concentrated markets. 
Pinto, B., Belka, M. \& Krajewski, S. (1993). Transforming State Enterprises in Poland: Evidence on adjustment by manufacturing firms. Brooking Papers on Economic Activity, 24, 213-270.

Pinto, B., \& van Wijnbergen, S. (1995). Ownership and corporate control in Poland: Why state firms defied the odds (No. 1273), CEPR Discussion Papers.

Rama, M. (1999). Efficient public sector downsizing. The World Bank.

Roland, G. (1993). The political economy of restructuring and privatization in Eastern Europe. European Economic Review, 37(2-3), 533-540.

Roland, G. (1994). On the speed and sequencing of privatisation and restructuring. The Economic Journal, 104(426), 1158-1168.

Roland, G., \& Sekkat, K. (2000). Managerial career concerns, privatization and restructuring in transition economies. European Economic Review, 44(10), 1857-1872.

Saygılı, Ş., \& Taymaz, E. (2001). Privatization, ownership and technical efficiency-A study of the Turkish Cement Industry. Annals of Public and Cooperative Economics, 72, 581-605.

Schusselbauer, G. (1999). Privatisation and restructuring in economies in transition: Theory and evidence revisited. Europe-Asia Studies, 51(1), 65-83.

Tache, I. (2008). The mass privatization process in Romania: A case of failed Anglo-Saxon capitalism. Article presented at the 10th bi-annual Conference of the EACES (European Association of Comparative Economic Studies), Moscow, 28-30. 
Ek 1. Verilerine Ulaşılan Özelleştirme Kapsamındaki Kiт’ler

\begin{tabular}{|l|}
\hline Adana Torba Sanayii T.A.Ş. \\
\hline ALPET \\
\hline Asil Çelik \\
\hline ÇiNKUR \\
\hline ÇiTOSAN \\
\hline Deniz Nakliyat \\
\hline DiTAŞ \\
\hline Et ve Balık Kurumu \\
\hline Gemi Sanayii \\
\hline Gerkonsan \\
\hline Hamitabat \\
\hline HAVAŞ \\
\hline IGSAŞ \\
\hline iSDEMiR \\
\hline KBi \\
\hline KEMERKÖY \\
\hline NiĞDE ÇIMENTO \\
\hline ORÜS \\
\hline PETKIM \\
\hline PETLAS \\
\hline SEK \\
\hline SEKA \\
\hline Sivas Demir Çelik \\
\hline Soma Elektrik \\
\hline Sümer Holding \\
\hline Sümerbank Holding \\
\hline T. Gemi Sanayii \\
\hline TAKSAN \\
\hline TDÇi \\
\hline TDi \\
\hline TEKEL \\
\hline TESTAŞ \\
\hline THT \\
\hline THY \\
\hline TÜGSAŞ \\
\hline TÜMOSAN \\
\hline TÜPRAŞ \\
\hline TURBAN \\
\hline TZDK \\
\hline YARPET \\
\hline YEM SANAYii \\
\hline YENiKÖY \\
\hline
\end{tabular}


This Page Intentionally Left Blank 